\title{
„KREDOWE KOLO” MYŚLICIELA A BADACZA. O PARADYGMATACH (KONTEKSTACH I PERSPEKTYWIE POSTRZEGANIA) W BADANIACH, KTÓRYCH PRZEDMIOTEM JEST MYŚL POLITYCZNA
}

\begin{abstract}
Celem artykułu jest przedstawienie analogii i różnic dotyczących kontekstów determinujących sytuację, w jakiej znajdują się: twórca myśli politycznej (przedmiot badań) i jej badacz - historyk idei, politolog. Odtwórcami tych ról mogą być zarówno pojedyncze osoby, jak i kolektywy (zespoły). Nawet jeśli przedmiotem rozważań są stosunki władzy, ustrój państwa, problemy polityki wewnętrznej i zagranicznej, to rozumienie, jaki wpływ na treść i zarazem formę przekazu myśli politycznej mają epoka, kultura, język, struktura społeczna (w której ulokowany jest myśliciel), alternatywne i współwystępujące ideologie, jest podstawowym wyzwaniem dla badacza. Analizując, rekonstruując myśl polityczną, bez wątpienia trzeba korzystać z metod jakościowych. Właściwe są paradygmaty teorii krytycznej lub konstruktywizmu.

Pierwszy z wymienionych zakłada, że rzeczywistość jest kształtowana przez wartości społeczne, polityczne, kulturowe, ekonomiczne (także etniczne i genderowe), co determinuje procesy poznawcze, ich komunikacyjny charakter i subiektywizm, to, że osiągane wyniki są zapośredniczone przez wartości. Z metodologicznego punktu widzenia powoduje to konieczność uwzględniania w procesie badawczym dialogiczności i dialektyki. Jeszcze bardziej relatywizujący pogląd na rzeczywistość społeczną charakteryzuje podejście konstruktywistyczne. Implikacją przyjęcia założenia, że rzeczywistości są konstruowane i rekonstruowane, jest też akceptacja współwytwarzania wyników przez badacza.

Metodologia badań opiera się na założeniu dialektyczności, dialogiczności, na hermeneutyce. Osiągany wynik badań nie jest neutralny z aksjologicznego punktu widzenia.

Żeby przedstawić przeszłe lub współczesne idee oraz inspirowaną nimi myśl polityczną trzeba przyjąc strategię tłumacza . W tym wypadku będzie to tłumaczenie kultur mających cechy tożsame i odrębne. Politolog powinien mieć kompetencje wykraczające poza jego dyscyplinę. Powinien być także historykiem, kulturoznawcą, antropologiem, filozofem (etykiem), językoznawcą (i oczywiście poliglotą), kompetentnym w zakresie procesów poznania i psychologii.
\end{abstract}

Słowa kluczowe: myśl polityczna, idee, metodologia, paradygmaty.

\section{WPROWADZENIE}

Do zastanowienia nad złożonością wymienionych w tytule ról inspirujecytat z książki Jerzego Szackiego poświęconej dylematom historii idei: „Każdy fenomen rozpatrywany w swym historycznym kontekście okazuje się racjonalny i konieczny. Wszystko zrozumieć to wszystko wybaczyć. Myśliciele nie mówią głupstw, nie bywają ograniczeni

${ }^{1}$ Dr hab. Magdalena Mikołajczyk, Instytut Politologii, Uniwersytet Pedagogiczny im. Komisji Edukacji Narodowej w Krakowie, ul. Podchorążych 2, 30-084 Kraków, tel.: 1266262 11, e-mail: dommik@up.krakow.pl 
czy tępi: mają zawsze do powiedzenia akurat tyle, ile pozwala im «epoka», «kultura», «język», «klasa», «paradygmat», «ideologia» itd. Każdy z nich jest zamknięty w jakimś kredowym kole i zadaniem historyka jest opisanie owego koła tak dokładnie, jak tylko potrafi, bez zgłaszania jakichkolwiek pretensji"'. Jakkolwiek autor w tym miejscutohistorykom (właściwie historykom idei) przypisuje potrzebę zrozumienia czynników determinujących kształt dowolnego rodzaju myśli znamiennej dla autora i jego czasów, równie istotne jest odniesienie dającej się odczytać z tego fragmentudyrektywy dotyczącej czynności podejmowanych przez politologów, badaczy teorii i myśli politycznej, takżewtedy gdy ich detaliczny i uściślony przedmiot badań dotyczy współczesnych diagnoz, refleksji nadżyciem politycznym, konstruktów -koncepcji zawierających opis obserwowanych zjawisk i projekty udoskonalonego organizowania politycznej domeny.

Celem artykułu jest pokazanie, że metaforyczne „kredowe koło” wytycza granice poznania nie tylko ludzi, którzy próbują zmagać się z pytaniami i kwestiami właściwymi ich czasom, ale także innych, motywowanych ambicją naukowego wyjaśniania, dlaczego dzieje się tak, a nie inaczej.Przeszli i współcześni badacze odnoszą się do obserwowanej praktyki politycznej, zastanawiają się, co jest tradycją, a co nowatorstwem, jakie mechanizmy właściwe są dziedzinie idei - adaptacji, dyfuzji, retrospekcji przewrotowej? Poza obszarem zainteresowań autorki niniejszego artykułupozostaje jednak samapragmatyka działań, stanowiąca - jak można zauważyć - inne jeszcze „kredowe koło". Takie, wktórym usytuowani są politycy, wszelkiego rodzaju decydenci, aktorzy obsadzeni w głównych rolach, a więc biorący udział w dyskursie politycznym.Inne zmienne stanowić będą o percepcji problemu, jego wyartykułowaniu (np. w autorskich wypowiedziach i publicystyce, partyjnych programach, w kampaniach politycznych, w tym wyborczych), włączeniu w zhierarchizowany system celów, propozycjach rozstrzygnięć. Nietożsame są natomiast zauważenie problemu i jego rozwiązanie, aspekt normatywny (modele postulatywne) i empiryczny obserwowanej polityki. W tym ostatnim wypadku wiąże się to $\mathrm{z}$ możliwym do wykorzystania instrumentarium, implementacją decyzji uprzednio dyskutowanych, dla których niezbędne jest polityczne poparcie określonej wielkości i rodzaju.Myśl, jak by nie była skrępowana, dysponuje większą swobodą, a przedstawianie wizji i alternatywnych algorytmów postępowania nie musi korespondować $\mathrm{z}$ istnieniem(co może się również wiązać $\mathrm{z}$ postrzeganiem) ograniczeń dających o sobie znać w świecie realnej polityki.Pomijając umiejętności diagnozowania problemów czy oryginalność koncepcji abstrakcyjnie tu przedstawianego myśliciela oraz oczekiwaną i hipotetycznie możliwą kongenialność narracji o myśli politycznej przygotowanej przez badacza, kimkolwiek by był, trzeba dokonać kilku zastrzeżeń związanych z wymienionymi tu postaciami (myśliciela i badacza).

\section{FIGURATYWNY ASPEKT BADAŃ MYŚLI POLITYCZNEJ (MYŚLICIEL I BADACZ)}

Sytuacja badacza, podobnie jak przedmiotu jego dociekań i analiz, którym tu jest myśl

2 J. Szacki, Dylematy historiografii idei oraz inne szkice $i$ studia, Warszawa 1991, s. 16. O podobnych dylematach, dotyczących refleksji nad polityką zob. A. Waśkiewicz, Dylematy historiografii teorii politycznej. Przedmiot a metoda interpretacji, [w:] Idee a urzadzanie świata społecznego. Księga jubileuszowa dla Jerzego Szackiego, red. E. Nowicka, M. Chałubiński, Warszawa 1999, s. 197-208. 
polityczna, jej źródła, a nader wszystkotwórcy, nigdy nie jest statyczna.Zarównomyśliciel, jak i idący jego tropem badacz, rekonstruujący idee, wyobrażenia, pomysły, schematy interpretacyjne, koincydencje uwikłane w kontekst czasu oraz miejsca, systemy aksjologiczne czy projektowane nowatorskie rozwiązania, są determinowani przez społeczne, polityczne, gospodarcze i kulturowe otoczenie. Przy czym wiąże się to $z$ jednostkową i zbiorową egzystencją, właściwościami interesujących tu podmiotów, ze splotem okoliczności rzutujących na możliwość percepcji i apercepcji, wypowiadania się i utrwalania owych wypowiedzi.

Polityka z jej wszelkimi właściwościami nie jest wyjątkowymobszarem refleksji dla tych, których interesują życie ludzkie, właściwości strukturalne i kondycja społeczeństwa, możliwość urządzenia świata na lepszych zasadach ${ }^{3}$. Myśl polityczna w nieunikniony sposób zawiera sięlub koresponduje $\mathrm{z}$ myślą społeczną. Myśliciel ma na uwadze dostrzegalne i dające się diagnozować problemy społeczne, to o nich się wypowiada, w ambitniejszej wersji pokazuje to wszystko, co w terminologii Michela Foucaultastanowi analizowane w przeszłości i aktualne gouvernementalitét .Problemy społeczne, warto dookreślić, nie oznaczato - socjalne, mogłyby być kojarzone z tym, co współcześnie nazywa się podziałami socjopolitycznymi, ważnymi w perspektywie polityki wewnętrznej(zatem in-) oraz uwarunkowaniami geopolitycznymi (zatem out-). Naukowe aspiracje polegać zaś mogą na systematyzacji, wyjaśnianiu, lokowaniu tej wyobraźni na potencjalnej mapie rozwiązań kreujących porządek społeczny, w tym stosunki władzy. Trudno odmówić wysiłku umysłowego jednych i drugich (myślicieli i badaczy) polegającego na interpretacji tradycji, dotychczasowego dorobku intelektualnego, uzupełnianiu go o nowe spostrzeżenia, twórczym przetwarzaniu idei i rozwiązań z przeszłości dla potrzeb warunkowanych bieżącą sytuacją (biorąc pod uwagę, że zmienna temporalna może się przyczyniać do prezentycznych zakłóceń w odbiorze intencji wcześniej piszącego $)^{5}$.

W obu wypadkach interesującei inspirującesą zagadnienia polityczne -dotyczące podmiotów i stosunków władzy, państwa, w tym jego ustroju, postrzeganych z jakiegoś punktu widzenia,relacji wewnętrznych i zewnętrznych konstytuujących politykę, dalej zaś idee $\mathrm{z}$ gatunku tych, które przez wieki rozpalały umysły,splatały i układały się w rozmaitego typu opozycje. Myśliciel nie podporządkowuje się jednak przyszłym

\footnotetext{
${ }^{3}$ Tak jak zainteresowań politycznych i kreatywności w tym zakresie nie da się przypisać ludziom określonej profesji, tak i badacze wywodzą się z różnych szkół i środowisk.Specyfikację naukowych zainteresowań myślą polityczną i sposób jej traktowania przez historyków, prawników, socjologów i filozofów opisał Ryszard Skarzyński. Zob. R. Skarzyński, Historia myśli politycznej w ujęciu politologicznym. Zarys koncepcji, „Studia Polityczne” 1992/1, s. 10-108.

${ }^{4} \mathrm{~W}$ polskich tłumaczeniach - rządomyślność lub urządzanie. Zob. M. Foucault, Filozofia, historia, polityka. Wybór pism, Wrocław 2000, s. 163-185; idem, Bezpieczeństwo, terytorium, populacja, Warszawa 2010, passim.

5 Quentin Skinner lokuje ten błąd interpretacji w możliwej, zdarzającej się „mitologii prowincjonalizmu", której egzemplifikacją są nastawienia badacza, nieuprawnione przypisywanie sensów, słowem - przystępowanie do badań przy góry przyjętych założeniach. Zob. Q. Skinner, Znaczenie $i$ rozumienie $w$ historii idei, „Refleksje” 2014/9, s. 147;http://politicalphilosophy.amu.edu.pl/wp-

content/uploads/q_skinner_znaczenie_i_rozumienie_w_historii_idei.pdf (dostęp: 30.10.2014). Pierwodruk tekstu: idem, Vision of Politics, Cambridge 2002, s. 57-89. Por. A. Waśkiewicz, Interpretacja teorii politycznej,Warszawa 1998, s. 81.
} 
badaniom, naukowej egzegezie wtłaczającej myśl w stworzone ramy interpretacji, wątki polityczne równie dobrze mogą być centralnym, jak i incydentalnym zainteresowaniem w szerszej, obejmującej więcej zagadnień koncepcji filozoficznej czy teorii społecznej. Rozumienie pojęć, koncepty składające się na przykład europejską lub polską tradycję stanowią nieustający obiekt zainteresowań dla osób identyfikujących się z tym kręgiem kulturowym. Są oczywiściewypadki transkontynentalnego transferu zainteresowań ${ }^{6}$. Innymi słowy, są myśliciele, których twórczość w pewnym sensie jest epokowa lub wiekopomna, konstytuujący nowe pojęcia, perspektywy, oceny, sposoby rozumienia zjawisk i procesów politycznych. Sito selekcji, właściwe dla kultury i współtworzone przez zbiorowości zainteresowane recepcją politycznych wątków, nie jest jednak perfekcyjnie skonstruowane -nikt nigdy nie zaręczy, że zapomnienie nie dotknęło kogoś oryginalnego, nie zaniechano badań tego rodzaju myśli, której dopiero rewaloryzacja ukazałaby ponadczasowy sens ${ }^{7}$.

Różnica ról sprowadza się w pewnym sensie do określenia tego, co pierwotne, a co wtórne, a także sposobu postrzegania i utrwalania, motywacji i celu. Metaforycznie można konstruować rozróżnienia niebędące opozycją: myśliciel-badacz, obserwatorinterpretator, konstruktor-dekonstruktor, krytyk rzeczywistości - krytyk obrazu rzeczywistości, konstytucjonalista - dokonujący wykładni, tkający narrację i snujący narrację o narracji badanej (tkacz i krawiec?), tubylec-antropolog. Niekoniecznie właściwe byłoby jednak zestawienie twórca-odtwórca, raczej należałoby to sformułować: percypujący-recypujący, a może jeszcze inaczej: osadzony w swoim czasie i swojej kulturze autor oraz tłumacz tego czasu i tej kultury, tłumacz czasem ideologicznie wyprofilowanych subkultur. Przy czym pojęcia „tłumacz”autorka niniejszego artykułu używatu w takim znaczeniu, jakie kiedyś przypisywałhumanistom Leszek Kołakowski w eseju rewaloryzującym znaczenie nauk $\mathrm{z}$ tego obszaru w świecie znaczonym postępem technologicznym i zdominowanym przez technokratów ${ }^{8}$.

Kreatywność w badaniu myśli politycznej, rzecz jasna, nie może polegać na imputowaniu myślicielowi postrzeganych lub - gorzej- pożądanych założeń, sposobów rozumowania i rozumienia, intencji i inspiracji. Co nie oznacza, że rola badacza musi być sprowadzona do schematycznego odtwarzania zawartości, jak możnajenazwać: dokumentów, tekstów czy świadectw,ich systematyzowania i wtórnego prezentowania w dyskursie.Inwencja będzie widoczna w konceptualizacji problematyki, w stawianych pytaniach, w odszukaniu tych kontekstów, które są niezaprzeczalnie ważne dla rozumienia. Gdyby chcieć to metaforycznie ująć: wadliwą postawą będzie taka, którąw realiach polskiego komunizmu przypisywano cenzorowi, gdy naprawiał kontestowane

${ }^{6}$ Po wyrywkowymsprawdzeniu koreańskich stron internetowych: Rousseau adnotowany jest 481000 razy, Arystoteles 472000, Hobbes 380000, Marks 212000, Róża Luksemburg 55400, Edmund Burke 34300. Nie ma niestety nawet transkrypcji nazwisk, takich jak Roman Dmowski czy Józef Piłsudski.

${ }^{7}$ Obrazowo przedstawiał to onegdaj polski filozof Paweł Beylin, pisząc: „W historii powszechnej znamy zwycięzców i tych, którzy ponieśli klęskę. Ale w historii myśli, podobnie jak w historii sztuki, zwycięstwo polega właśnie na tym, że się do niej weszło. Ilu poniosło klęskę? Czy nie należałoby na wzór pomnika Nieznanego Żołnierza wystawić pomnika nieznanym artystom i nieznanym filozofom?”. P. Beylin, Autentyczność i kicze, Warszawa 1975, s. 324.

${ }^{8}$ L. Kołakowski, Wielkie i mate kompleksy humanistów, [w:] idem, Kultura i fetysze, Warszawa 1967, s. 285. 
wypowiedzi (cenzor jako współautor), warto natomiast zastanowić się nad wysiłkiem, jaki Clifford Geertz identyfikował z powstaniem i konstrukcją dzieł wybitnych antropologów (antropolog jako autor) ${ }^{9}$.

Jakkolwiek będzie się definiować myśliciela i badacza, funkcje procesów poznawczych, inaczej podmiotowo zorientowanych, są różne ${ }^{10}$. W przeszłości myśliciel zawsze kojarzony był z ujawniającą swoje zdanie osobą, współcześnie można w tej roli obsadzać grupę czy krąg społeczny.Rezultat badań także może być efektem kolektywnych zabiegów.Interesujące są przecież idee konstytuujące ruchy społeczne, pomysły artykułowane w partyjnych programach, polemiki i spory toczące się wewnątrz lub na styku różnych środowisk, współkształtujące rozumienie polityki i polityczną kulturę. Wówczas celem staje się uchwycenie dynamiki myśli, jej dialogicznego charakteru, modalnych, a także zaskakująco oryginalnych i skrajnych poglądów.Rekonstrukcja ,życia idei” to zkolei wędrówka zarówno przez wieki, jak i przez państwa czy kontynenty, niegdyś możliwa, coraz trudniejsza w czasach hipertrofii informacyjnej i wszechobecności cyberprzestrzeni. Wielkość zasobu, jaki stanowią świadectwa współczesnej myśli politycznej, ich niejednorodność i zróżnicowanie, warunkowany cyfrową rewolucją augiaszowy wręcz przyrost,może wpływać na konieczność traktowania ich jak big data, gdzie ukrywa się być może zapis idei politycznych właściwych współczesności - dotarcie do nich wymaga synchronizacji wysiłków lub zmiany warsztatu. Druga strona medalu jest nader banalna (uwikłana w dodatku w wyraźny kontekst znaczeniowy) - koniecznością staje się organizowanie większych umiędzynarodowionych grup badaczy, samą ideą bowiem żyć się nie da.

\section{MYŚL POLITYCZNA JAKO PRZEDMIOT BADAŃ}

Znaczenie i zakres pojęć, takich jak „idea/idee”, „myśl polityczna”, „doktryna” czy ostatecznie ,ideologia”, są bez wątpienia różne. Między historią doktryn politycznych (aspirującą do wszechstronnej prezentacji, systematyzacji, komparatystyki i syntezowania dokonań kognitywno-konceptualnych odnoszących się do sfery polityki wraz z historiozoficznymi uogólnieniami), historią idei oraz badaniami myśli politycznej zorientowanymi zarównohistorycznie, jak i na współczesność nie ma takich cezur, które dla każdej z tych subdyscyplin tworzyłyby odmienne pola badawcze czy decydowały o

\footnotetext{
${ }^{9}$ M. Fik, Cenzor jako wspótautor, „Tygodnik Powszechny” 1995/4 s. 1, 5; C. Geertz, Dzieło i życie. Antropolog jako autor, Warszawa 2000.

${ }^{10}$ Trudno rozstrzygać, jaki rodzaj motywacji i pragmatyki ma znaczenie podstawowe. Ci, którzy myśl polityczną kreują, mogą być motywowani instrumentalnie i autotelicznie. Trafnie zauważa jednak Wiesław Władyka w recenzji jednej z polskich monografii poświęconych historii myśli politycznej (M. Król, Historia myśli politycznej, Gdańsk 1998): „dramat myślicieli politycznych polega na tym, że albo nikt ich nie czyta, albo jeżeli czyta, to nie rozumie, a jeżeli nawet rozumie, to nie stosuje sie do ich rad”. Zob. W. Władyka, Lęki na koniec wieku, „Polityka” 1999/2, s. 58. Natomiast redaktor i autor jednej z książek przedstawiających współczesną sytuację ukraińską (historię, podziały socjopolityczne, ruchy, partie i ideologie), Klaus Bachmann, na pytanie, do kogo skierowany jest ten projekt, żartobliwie odpowiada, że głównie do Ministerstwa Nauki i Szkolnictwa Wyższego, które chciałoby, by naukowcy „wyszli w świat i obwieszczali, co mają do powiedzenia”. Cyt. za:http://audycje.tokfm.pl/\#TRNavSST (dostęp: 30.10.2014). Zob. The Maidan Uprising, Separatism and Foreign Intervention,red. K. Bachmann, I. Lyubashenko, Frankfurt am Main, Berlin, Bern, Bruxelles, New York, Oxford, Wien 2014.
} 
niemożności zastosowania podobnych czy wręcz tożsamych założeń, podejść badawczych i metod. Można wyodrębniać pole właściwe tym subdyscyplinom lokującym się w zarówno obszarze nauk humanistycznych (historia), jak i społecznych (politologia) i prawnych (gdy w centrum uwagi lokowane jest państwo), starać się je separować lub przeciwnie - scalać.Równie dobrze można przyjąć, że jest to wyłącznie rozgraniczenie o nominalnym charakterze, dokonujące się na poziomie języka, tradycji badawczych, identyfikacji z którąś z wyróżnianych szkół. W ten sposób studia nad zagadnieniami filozofii politycznej prowadzone na jednym kontynencie mogą korespondować $\mathrm{z}$ badaniami myśli politycznej i historii idei na drugim.

Próby rozgraniczenia $\mathrm{w}$ niektórych ujęciach wiążą myśl polityczną $\mathrm{z}$ opiniami wyrażanymi na temat potrzeb grup społecznych oraz stanem refleksji formułowanej wobec spraw publicznych, teorię polityki z próbami wyjaśnienia postaw i działań politycznych, filozofię polityczną zaś z rozumieniem konfliktów zrelatywizowanych okolicznościami, analizą terminologii i koncepcji oraz próbami ustalenia i dowodzenia racji atrakcyjnych z etycznego punktu widzenia ${ }^{11}$.W próbach delimitacji pola badawczego historii idei, a tym samym zadań stojących przed badaczami identyfikującymi swoje zainteresowania z tą dziedzinąmożna znaleźć zawężenie dotyczące potencjalnych źródeł (kanon klasycznych tekstów) oraz rozszerzenie zakresu pytań badawczych obejmujących już nie tylko kwestie polityki, ale i religii, moralności itp.Quentin Skinner efektywnie zbija przekonanie, że analizowane i interpretowane teksty dotycząc ponadczasowych zagadnień i fundamentalnych idei stanowią wartość dla kumulatywnie traktowanej humanistycznej wiedzy, dlatego też w nich znaleźć można odpowiedzi odnoszące się do różnych dziedzin i wartości życia społecznego ${ }^{12}$.Rola idei jest niekwestionowana, także politycznych - podkreślane jest ich znaczenie poznawcze i praktyczne. Specyfiką Cambridge school,której przedstawicielem jest wymieniony Skinner,staje się akcentowanie złożoności, różnorodności, istnienia naturalnych napięć i niekonsekwencji, przekładające się na nietożsame oceny dziedzictwa, a co za tym idzie - konieczność uwzględnienia tego $\mathrm{W}$ metodologii badań. W historii idei $\mathrm{W}$ ten sposób postrzeganejsprzeczności są naturalne, kolizja idei ilustruje konflikty między grupami społecznymi, znamiennymi dla nich wzorami zachowań. Polityka skojarzona z budową wspólnoty i reguł ją organizujących implikuje rozumienie myśli politycznej. Tajest przedstawianąartykulacją „,społecznego doświadczenia w budowie owego ładu; zapisem, w którym uwzględniony jest dynamiczny związek między działaniem a refleksją nad nim"13. Andrzej Waśkiewicz, charakteryzujący w ten sposób podejścia brytyjskich badaczy, dodaje, że tradycja, rozumiana tu jako całość współkształtowana przez „zachowania, mówienie i myślenie o polityce”, jest koniecznym warunkiem komunikacji wewnątrz wspólnoty, ma wpływ na jej tożsamość (z uwzględnieniem diachronii i synchronii).

Zakres pojęcia „myśl polityczna” wyznaczany jest z największym rozmachem. Poświadcza to nie tylkowielejuż zaprezentowanych interpretacji, ale także popularna i często przytaczana przez polskich badaczy definicja przyjęta w ośrodku lubelskim, w której akcentowane są kryteria przedmiotowe - myśl musi dotyczyć szeroko pojmowanej rzeczywistości politycznej, marginalizowane zaś są po pierwszekryteria podmiotowe

${ }^{11}$ B. Crick, Philosophy, Theory and Thought,,,Political Studies” 1967/15, s.49.

${ }^{12}$ Q. Skinner, Znaczenie i rozumienie...,s. 127-169.

${ }^{13}$ A. Waśkiewicz, Interpretacja teorii..., s. 86. 
orazpo drugiezwiązane z możliwością jej czytelnego ustrukturyzowania. Pierwsze stanowi pochodną egalitaryzacji obserwowalnej w rozwoju doktryn, przyjęcia przez badaczy już pod koniec XIX w., że wartościowe poznawczo są koncepcje tworzone na różnych piętrach struktur społecznych, politycznych, związanych z życiem naukowym i szerzej intelektualnym. Dzieje myśli politycznej nie muszą być zatem, jak to błyskotliwie sformułował Jan Baszkiewicz, opisem: „wielkiej konwersacji toczonej przez wieki w gronie tytanów intelektu" ${ }^{14}$.Myśliciela, kiedyś nieodzownie filozofa produkującego dzieła, zastępuje podmiot o mniej lub bardziej zinstytucjonalizowanym charakterze, nierzadko zbiorowość autorów wypowiadających się na określony temat, połączonych zauważalną nicią porozumienia. $\mathrm{W}$ drugim wypadku podkreśla się, że dla myśli politycznej nie ma znaczenia wewnętrzna spójność, usystematyzowanie, konkretyzacja czy możliwość przekształcenia poglądów, koncepcji w jakikolwiek system o bardziej teoretycznych (tym samym eksplanacyjnych) walorach ${ }^{15}$. W dyskusji toczącej się wokół pojęć,takich jak „,ideologia”, „doktryna”, „myśl polityczna”, i procesów tworzenia tej ostatniej, podnosi się kwestie nieredukowania zakresu nazwy, nieignorowania ideowotwórczych oddziaływań myśli politycznej. Takie podejście zwraca uwagę na relację myśl polityczna - teoria polityczna, wartości, cele oraz szerzej zorientowane programy działania (wizje) oraz style myślenia $^{16}$.

Zarównohistoria myśli politycznej, jak i współczesna myśl polityczna są w świetle tego ważne dla politologicznie zorientowanych badań ${ }^{17}$. Nietrudno znaleźć uzasadnienia, szczególnie wtedy, gdy politologia przedstawiana jestjako dyscyplina nauki, wprawdzie usytuowana relatywnie nisko $\mathrm{w}$ potencjalnym rankingu nauk o człowieku, jednak gromadząca i przetwarzająca informacje o wielu aspektach jego działań. Tadeusz Klementewicz zainteresowania myślą polityczną sytuuje w obszarzebadań dotyczących form kultury (świadomości) uczestników polityki. Badacze myśli politycznej dołączają do grona tych, których interesują kultura polityczna, opinia publiczna, czynniki różnicujące partie polityczne, różne formy świadomości i tożsamości (narodowej, klasowej,

\footnotetext{
${ }^{14}$ Cyt. za: K. Chojnicka, H. Olszewski, Historia doktryn politycznych i prawnych. Podręcznik akademicki, Poznań 2004, s.11.

${ }^{15}$ W. Paruch, Od konsolidacji państwowej do konsolidacji narodowej: mniejszości narodowe w myśli politycznej obozu pitsudczykowskiego (1926-1939), Lublin 1997, s. 13; idem, Myśl polityczna - refleksje metodologiczne o pojęciu,,Annales Universitatis Mariae Curie-Skłodowska. Sectio K Politologia" 1999/6, s. 27-39; idem, Między wyobrażeniami a dziataniami : wybrane aspekty przedmiotowe badań politologicznych nad myśla polityczna, „Polityka i Społeczeństwo” 2004/1, s. 9-38; idem, Myśl polityczna obozu pitsudczykowskiego: 1926-1939, Lublin 2005, s. 10; idem, Kategorie ekonomiczne a zakres pojęcia myśl polityczna - refleksje metodologiczne, [w:] Idee, państwo, ludowcy. Księga jubileuszowa z okazji 70. rocznicy urodzin Profesora Jana Jachymka, red. E. Maj, S. Michałowski, A. Wójcik, Lublin 2009, s. 37-46; W. Paruch, K. Trembicka, Myśl polityczna we wspótczesnej polskiej politologii: modernizacja przedmiotu, strategii $i$ metody działań, [w:] Politologia w Polsce. Stan Badań i perspektywy, red. M. Ciochosz, K. Zamorska, Wrocław 2006, s. 207-220; E. Ponczek, Polska myśl polityczna: ciagłość tradycji a koherencja aksjologiczna, [w:] Między otwarta a domknięta myśla polityczną. Szkice o najnowszej refleksji politycznej, Toruń 2006, s. 38-49.

${ }^{16}$ W. Paruch, Między wyobrażeniami a dziataniami...,s. 16-17.

17 Istotę politologicznego podejścia do historii myśli politycznych wyznaczają stawiane przez badacza pytania o polityczność idei, ich funkcjonalność wobec podmiotów polityki (ich egzystencji i aktywności). Zob. R. Skarzyński, Historia myśli politycznej...,s. 110.
} 
państwowej) -tę specyfikację można uzupełniać zagadnieniami z zakresu socjologii polityki, dotyczącymi politycznych preferencji oraz zachowań wyborczych ${ }^{18}$.

\section{KREDOWE KOLO BADACZA}

Istotne jest usytuowanie obu - myśliciela i badacza- w czasie, przestrzeni, zbiorowościach i strukturze społecznej.Innymi słowy,zmienne historyczne, geograficzne i socjologiczne, wyznaczające kontekst, nie dają się bagatelizować. Dystans, którym mogą być dekady, stulecia czy całe epoki, tworzy barierę nie tylko językową, ale równieższerzej kulturową oraz - w wynikuodniesienia do kodu komunikacyjnego i spersonalizowanie mentalną. Zmiana, jaką trzeba uwzględniać, dotyczy zarównowłaściwości polityki, w tym rozszerzania grona osób wypowiadających się o niej, jak i środków komunikowania. Miejsce, krąg kulturowy, państwo czy narodowość, zakorzeniając w tradycji myśliciela i badacza,tworzą system odniesień sobie właściwych i niekonieczne dających się zrozumieć przez innych. Język nie może być traktowany wyłącznie jako system znaków, prędzej jako ukształtowany społecznie sposób wypowiedzi, medium umożliwiające komunikowanie znaczeń $\mathrm{i}$ form wiedzy. To także system znaczeńkulturowych ( $\mathrm{z}$ tego powodu relatywnych) odniesionych do polityki (w którym poprzez dekonstrukcję można szukać ukrytych założeń), nośnik emocji, a więc idei, nietożsamy dla wspólnot zróżnicowanych czasem i przestrzenią(oczywiście narodowych, ale teżwspółcześnie historycznie zmiennych). O tym jakie to trudne przypomina figura innego jeszcze koła hermeneutycznego. O tym, jak mało jest wspólnych pojęć - idei podzielanych w różnych kulturach-przekonująco dowodząbadania Anny Wierzbickiej ${ }^{19}$.

Tylko w pewnym stopniustawia to w lepszej sytuacji badacza myśli współczesnej, zorientowanego na poznanie odzwierciedlonego w rodzimej myśli politycznej obrazu „dążeń, aspiracji, wysiłków i zmagań, sukcesów i porażek jednostek oraz grup społecznych, organizacji, a także instytucji, usiłujących, poprzez zdobycie i sprawowanie władzy państwowej lub wywieranie na nią wpływu, osiągnąc zamierzone cele i zadania ${ }^{20}$.Być może uniewrażliwia go na ideologiczne nasycenie studiowanych źródeł, świadectw, egzemplifikacji w postaci coraz bardziej zróżnicowanych form przekazu. Niedorzecznym wydawałoby się pytanie, czy myśl polityczna może nie być zideologizowana. Szczególnie gdy ideologię zdefiniuje się nie tylko jako nacechowany

\footnotetext{
18 T. Klementewicz, Politolog w labiryncie paradygmatów - pułapki eklektyzmu, [w:] Podejścia badawcze i metodologie w nauce o polityce, red. B. Krauz-Mozer, P. Ścigaj, Kraków 2013, s. 32.

19 Najciekawszym przykładem jest, wydawałoby się uniwersalne, pojęcie wolności, nie identyfikowane w wielu językach. Zob. A. Wierzbicka, Stowa klucze. Różne języki. Różne kultury, Warszawa 2007, s. 289.

${ }^{20}$ Nieprzypadkowo użyto tego cytatu. W badaniach współczesnej polskiej myśli politycznej często podkreślany jest ów instytucjonalny charakter „myśliciela”. Zob. M. Śliwa, Idee polityczne w Polsce, Ostrowiec Świętokrzyski 2004, s. 5.Na dorobku „ideowo-politycznym partii i ugrupowań politycznych", dającym się skategoryzować nieinstytucjonalnie poprzez wyróżnienie nurtów, koncentrują się autorzy jednego $\mathrm{z}$ bardziej wyczerpujących opracowań.Prezentację nurtów uznanych za reprezentatywne dla polskiej współczesnej myśli politycznej poprzedziła analiza dorobku osób, uznanych za „wybitnych i twórczych przedstawicieli, którzy decydowali o obliczu ideowym nurtu”. Są to: „myśliciele, ideolodzy, autorzy programów partyjnych, publicyści i eseiści”. Zob. E. Maj, A. Wójcik, Wstęp,[w:] Myśl polityczna w Polsce po 1989 roku. Wybrane nurty ideowe, Lublin 2008, s. 9-10.
} 
aksjologicznie system poglądów,lecz jako społeczną reprezentację grupy, funkcjonalnąwobecpoczuciajej tożsamości i solidarności,motywującą do działań, wykazującą znaczenie psychologiczne ${ }^{21}$. Właściwością kredowego koła jest jednak to, że poszczególny zespół poglądów może nie wykazywać cech ideologicznychz endogennej perspektywy - gdy badacz wywodzi się z danej grupy, podziela obecne w niej przekonania, z perspektywyczasu zawsze owo ideologiczne nasycenie jest wyrazistsze, podobnie jak zbiorowości i struktury, w których ulokowany był myśliciel.

Miejsce w strukturze społecznej, status, wykształcenie, w tym erudycja i horyzonty intelektualne, biografie $\mathrm{z}$ doświadczeniami i ukształtowanym modelem mentalnym, środowiskowe więzi i preferencje polityczne - wszystko to stanowi pryzmat, przez jaki filtrowane są obserwacje, przyczynę naturalnej skądinąd selektywności i zarzewie różnego rodzaju „centryzmów”22. Niektóre tematy wydają się bardziej interesujące nie dlatego, że takimi były dla zbiorowości wcześniejszych, grup domniemanego myśliciela, ale ponieważw czasie właściwym dla badacza (w jego teraźniejszości) temat nabiera nowego znaczenia, może lub wręcz powinien być reaktywowany. Błędy możliwe do popełniania, które Skinner nazywa mitologiami, wykazując niedorzeczności na przykładw przypisywaniu klasycznym myślicielom ukształtowanie doktryny, obarczanie ich własnymi uprzedzeniami, czytanie ich tekstów z nastawieniem, z przyjętymi z góry paradygmatami, niewłaściwe odczytywanie znaczeń itp. - może to dotyczyć interpretacji tekstów również współczesnych ${ }^{23}$.

Ciekawym pytaniem staje się to,na ile i w jaki sposób współczesność z jej wyzwaniami staje się inspiracją do poszukiwań, w dodatku po tej stronie, która wykazuje zbieżność z uświadamianymi bądź nie preferencjami badacza. Gdyby szukać egzemplifikacji tego przypadku, należałoby rozważyć chociażby renesans zainteresowań w polskich badaniach myślą polityczną Carla Schmitta czy frekwencję badań zorientowanych na myśl narodową i nacjonalizm.

\footnotetext{
${ }^{21}$ Teun van Dijk przez ideologię rozumie system przekonań podzielanych przez grupę, decydujący o tożsamości grupy i mający zdolność do kontroli jej zachowań, który nie jest jednak redukowany do polityki. Rozróżnia ideologie polityczne, społeczne, nawet zawodowe. W propozycji badań dyskursu operuje pojęciami wspólnej bazy kulturowej (pojęć, przekonań podzielanych w danej kulturze, nienacechowanych ideologicznie), ideologii (stanowiącej selektywnie dobrany zbiór przekonań) oraz pozwalających rozumieć i analizować dyskurs pojeć nazwanych tu modelem kontekstu oraz modelami mentalnymi wypowiadających się. T.A. van Dijk, Ideology. The Multidiscyplinary Approach, London 1998, passim. Zob. także: idem, Dyskurs polityczny i ideologia, „Etnolingwistyka” 2003/15, s. 7-28.

22 Mam tu na myśli dominującą perspektywę i tradycje badań amerykańskich i brytyjskich, europocentryzm i polonocentryzm. Coraz więcej prac poświęconych innym tradycjom (choć najczęściej publikowanych przez wydawnictwa anglosaskie) dostępnych jest on-line. Zob. Contemporary Chinese Political Thought: Debates and Perspectives, red. F. Reinhard Dallmayr, T. Zhao, Kentucky 2012; G. Martin, African Political Thought, New York 2012; A. Black, The History of Islamic Political Thought: From the Prophet to the Present, Edinburg 2011; U. Sharma, S.K. Sharma, Indian Political Thought $t_{2}$ ew Delhi 1996; K.S. Padhy, Indian Political Thought, New Delhi 2011; Comparative Political Thought: Theorizing Practices,red. M. Freeden, A. Vincent, Abingdon 2013; Contemporary Latin American Social and Political Thought: An Anthology,red.I. Márquez, Plymouth 2007.

${ }^{23}$ Q. Skinner, Znaczenie i rozumienie...,s. 130-160.
} 


\section{W SIECI KONKURENCYJNYCH PARADYGMATÓW}

Pojęcie ,paradygmat” jest słowem-kluczem, używanym w znaczeniach niekoniecznie zbieżnych z rozumieniem go przez autora Struktury rewolucjinaukowych ${ }^{24}$. Oczywiście w naukach społecznych konstytuowane są modele postępowania, w których ustala się, co jest zaobserwowane, co warto obserwować, które kwestie są istotne i jakie pytania należy stawiać, jakie procedury postępowania uprawdopodobnią prawdziwość odpowiedzi. Paradygmat odnosi się zatem do metodologii badań i w takim sensie warto się nad tym w tym miejscu zastanowić, choć niewątpliwie należy myśleć raczej o wielości, zróżnicowaniu, konkurencyjności paradygmatów ${ }^{25}$. Co nie znaczy, że historycy doktryn, badacze myśli politycznej nie chcą identyfikować paradygmatów organizujących badane wypowiedzi, odnosząc to pojęcie po prostu do przekonań mających zdolność trwania w dłuższych okresach ${ }^{26}$. W odniesieniu do subdyscypliny, jaką stanowią historyczne lub uwspółcześnione badania myśli politycznej, czymś innym jest metodologicznie poprawne przygotowanie badań (bez względu na to, czy wyodrębnienie problematyki nazwie się przygotowaniem kwestionariusza pytań badawczych), czymś innymnatomiast pragnieniepełnej standaryzacji ${ }^{27}$.

Myśl polityczna, jak wcześniej zaznaczono, znajduje się w orbicie zainteresowań badaczy o różnego rodzaju profesjonalizmie. Dlategoróżne są stawiane pytania, odmienność podejść, perspektyw i warsztatów badawczych. Gdy dla historyka istotniejsze jest to, jak idee kształtują zachowania społeczne, w centrum zainteresowań historyka idei lokują się same idee, istotniejsza wydaje się ich geneza, konstrukcje ich egzemplifikacji, przenikanie, wędrówka, stosunki polityczne leżące u ich podłoża, rzutujące na ich trwanie czynniki społeczne i ekonomiczne. Stosowane podejścia badawcze, przyjęte założenia i dyrektywy metodologiczne mogą być różne. Dla badaczy z kręgu warszawskiej szkoły historii idei jednostką badaną był światopogląd i choć niewiele nazwisk badaczy można zidentyfikować $\mathrm{z}$ tym zespołem, każdy $\mathrm{z}$ nich stosował nieco inną metodę. W jednym

\footnotetext{
${ }^{24}$ T.S. Kuhn, Struktura rewolucji naukowych,Warszawa 1968.

${ }^{25} \mathrm{O}$ wieloparadygmatyczności nauk społecznych, w tym politologii, często wspomina się w polskim najnowszym piśmiennictwie. Zob. T. Klementewicz, Politolog $w$ labiryncie paradygmatów...,s. 31-43; idem, Politologia jako wieloparadygmatyczna struktura wiedzy, „EPoliticon” 2013/5, http://oapuw.pl/wp-content/uploads/2013/08/Klementewicz-T..pdf; A. W. Jabłoński, Paradygmaty wyjaśniania w naukach społecznych, [w;] Aspekty metodologiczne oraz teoretyczne w subdyscyplinach politologii,red. Ł. Młyńczak, B. Nitschke, Toruń 2013, s. 72-88; T. Łoś-Nowak, Wyjaśniać czy interpretować: dylematy $i$ wyzwania czwartej debaty interparadygmatycznej. Refleksje nad stanem dyscypliny, [w:] Demokratyczna Polska w globalizującym się świecie, red. K.A. Wojtaszczyka, A. Mirskiej, Warszawa 2009; K. Michalski, Interdyscyplinarność, transdyscyplinarność, multidyscyplinarność: nowy paradygmat $w$ nauce $i$ badaniach,,Zeszyty Naukowe Politechniki Rzeszowskiej. Ekonomia i Nauki Humanistyczne” 2007/16, s. 83-100.

${ }^{26}$ Zob. np. A. Łuszczyński, Paradygmaty w historii doktryn polityczno-prawnych, [w;] Kontynuacje i nowatorstwo w świecie wspótczesnych idei, red. M. Mikołajczyk, M. Śliwa, Kraków 2008, s. 1623.

27 Pojęcia kwestionariusz pytań badawczych używa wielu autorów. Zob. np. W. Paruch, Od konsolidacji państwowej..., s. 14; K. Kawalec, Wizje ustroju państwa w polskiej myśli politycznej lat 1918-1939: ze studiów nad dziejami polskiej myśli politycznej, Wrocław 1995, s. 8. Próbę ilościowego potraktowania myśli politycznej znaleźć można w:K. Jajecznik, Myśl polityczna próba standaryzacji badań, „Political Science Annual”2006/9, s. 255-270.
} 
wypadku opierałasię ona na próbie tworzenia konstruktów idealnych, przerysowujących to, co widoczne w materiale źródłowym,z uzasadnieniem, że tylko takie modele nadają faktom sens (Leszek Kołakowski i metoda ekspresjonistyczna), w kolejnym charakterystyczne było eksponowanie dychotomii, antagonizmów, niespójności, niedookreśloności (Bronisław Baczko). Andrzej Walicki, dokonujący retrospektywnego przeglądu przeszłych dokonań, zaznacza, że jego sposób podejścia to badanie myśli i myślicieli w złożonym wielowymiarowym kontekście - historycznym, literackim, krytycznoliterackim, religijnym, narodowym, porównawczym ${ }^{28}$.

Badania myśli politycznej zasadzają się nie tylko na umiejętnym zarysowaniu kontekstu, przedstawieniu wizji ustroju i poglądów na wieleszczegółowych polityk, także na skrupulatnym zrekonstruowaniu różnych argumentacji, pojawiających się w myśli politycznej norm dotyczących standardów życia publicznego, charakterystycznych dla analizowanych podmiotów wyobrażeń (ich powstawania, zauważalnej intuicji, wnikliwości), genezy poglądów i ich ewolucji, utrwalających pewne sposoby myśleniaparadygmatów, „morfologii i klastrów koncepcyjnych"29. Hipotetyczny, przedstawiany tu badacz również szuka idei, rekonstruując zawarte w swoistych dla badanej myśli źródłach różnego rodzaju przekonania, poglądy, rozumowania, perspektywy oceny. Interesują go wybrane (czasem koniunkturalnie) tematy i treści, stosowane schematy. Ponadto zwraca uwagę na tradycje, zakorzenienia, kontynuacje, uzupełnienia, kontaminacje. Interesują go zespoły poglądów układające się w nurty, meandrujące; może w odniesieniu do przedmiotu swoich badań użyć terminów: panorama, spektrum i kontinuum. Zwraca uwagę na powtarzalność, modalność, odchylenia i różnice. Analizuje hierarchie, kierunki, odniesienia i powiązania, procesualność - myśl bowiem kształtuje się, dojrzewa, ma swoją dynamikę, jest dyskursywna. Pod siecią znaczeń prostych i czytelnych szuka tych ukrytych, o które w polityce nietrudno. Deskrypcja i analiza powinna przypominać „opis gęsty” Cliforda Geertza: podmieniwszy sam przedmiot, zastępuje ważne dla antropologa działania i ich sensy - politycznymi wypowiedziami i ich sensem ${ }^{30}$.

\section{PODSUMOWANIE}

Badania myśli politycznej mają z natury charakter jakościowy, warto zatem zauważyć przesunięcia $\mathrm{i}$ dopowiedzenia stosowane przez metodologów odnoszących się do podobnej materii. Instruktywne jest uzupełnianie możliwych do wykorzystania w naukach społecznych paradygmatów o charakterystyki obrazujące nie tylko zmiany założeń o naturze rzeczywistości społecznej, ale także uwzględniające stopniowalne uczestnictwo czy zaangażowanie badacza. Postpozytywistyczna metodologia wymaga falsyfikacji hipotez, z dystansem podchodząc do jakościowych metod i technik. Promuje neutralność badacza. Paradygmat kojarzony $\mathrm{z}$ teorią krytyczną zakłada, że rzeczywistość jest kształtowana przez wartości społeczne, polityczne, kulturowe, ekonomiczne (także etniczne i genderowe), co determinuje procesy poznawcze, ich transakcyjność i

\footnotetext{
${ }^{28}$ Dyskusja „Warszawska szkoła historii idei - powstanie przeksztatcenia, kontynuacje”, [w:]Wokót dorobku warszawskiej szkoty historii idei, red. A. Kołakowski, Warszawa 2013, s. 12-21.

${ }^{29}$ M. Freeden, Ideology, Political Theory and Pholitical Philosophy,[w:] Handbook of Political Theory,red. G. F. Gaus, Ch. Kukathas, London 2004, s. 3.

30 C. Geertz, W strone interpretatywnej teorii kultury, [w:] Badanie kultury. Elementy teorii antropologicznej,red. M. Kempy, E. Nowicka, Warszawa 2005, s. 35-58.
} 
subiektywizm,to, że osiągane wyniki są zapośredniczone przez wartości. Z metodologicznego punktu widzenia powoduje to konieczność uwzględniania w procesie badawczym dialogiczności i dialektyki. Jeszcze bardziej relatywizujący pogląd na rzeczywistość społeczną charakteryzuje podejście konstruktywistyczne. Implikacją przyjęcia założenia, że rzeczywistości są konstruowane i rekonstruowane, jest też akceptacja współwytwarzania wyników przez badacza i konieczna do stosowania metodologia właściwa hermeneutyce ${ }^{31}$. Nietrudno dostrzec, że błędy pojawiające się w badaniach myśli politycznej, które wynikają z arbitralności przekonań badacza, stoją jakby na przekór założeniom właściwie któregokolwiek z wymienionych paradygmatów.

Aby kongenialnie przedstawićdawną lub współczesną myśl polityczną,nasz hipotetyczny badacz, nawet jeśli identyfikuje się ze skądinąd ekskluzywnym zawodem politologa, powinienbyć zarazem historykiem, kulturoznawcą, antropologiem, filozofem (z naciskiem na etykę), językoznawcą (oprócz tego, że poliglotą), kognitywistą i psychologiem.W dodatku powinien być świadomy konsekwencji przyjętego paradygmatu, towarzyszących mu implikacji metodologicznych. Zdając sobie jednak sprawę, że już wybór przedmiotu badań poniekąd określa jego samego, w rozgraniczaniu poglądów własnych i cudzych strzec się powinien przed wszelkimi mitologiami,opisanymi przez Skinnera, odniesionymi do jego dyscypliny.

\section{LITERATURA}

[1] Crick B., Philosophy, Theory and Thought,,Political Studies” 1967/15, s.49.

[2] Dijk T.A. van,Ideology. The Multidiscyplinary Approach, London 1998.

[3] Dijk T. A. van,Dyskurs polityczny i ideologia, „Etnolingwistyka” 2003.

[4] Foucault M., Bezpieczeństwo, terytorium, populacja, Warszawa 2010.

[5] Geertz C., W strone interpretatywnej teorii kultury, [w:] Badanie kultury. Elementy teorii antropologicznej,red. M. Kempy, E. Nowicka,Warszawa 2005.

[6] Guba E.G., Lincoln Y.S., Kontrowersje wokót paradygmatów, sprzeczności $i$ wytaniajace się zbieżności, [w:] Metody badań jakościowych, red. N. K. Denzin, Y. S. Lincoln, t. 1, Warszawa 2009.

[7] Jabłoński A.W., Paradygmaty wyjaśniania w naukach społecznych, [w:] Aspekty metodologiczne oraz teoretyczne $w$ subdyscyplinach politologii, red. Ł. Młyńczak, B. Nitschke, Toruń 2013.

[8] Jajecznik K., Myśl polityczna -próba standaryzacji badań, „Political Science Annual'2006/9.

[9] Kawalec K., Wizje ustroju państwa w polskiej myśli politycznej lat 1918-1939: ze studiów nad dziejami polskiej myśli politycznej,Wrocław 1995.

[10] Klementewicz T., Politolog w labiryncie paradygmatów - pułapki eklektyzmu, [w:] Podejścia badawcze i metodologie w nauce o polityce, red. B. Krauz-Mozer, P. Ścigaj, Kraków 2013.

[11]Łuszczyński A., Paradygmaty $w$ historii doktryn polityczno-prawnych, [w;] Kontynuacje i nowatorstwo w świecie wspótczesnych idei, red. M. Mikołajczyk, M. Śliwa, Kraków 2008.

\footnotetext{
${ }^{31}$ Zob. E.G. Guba, Y.S. Lincoln, Kontrowersje wokót paradygmatów, sprzeczności i wyłaniajace się zbieżności,[w:] Metody badań jakościowych, red. N.K. Denzin, Y.S. Lincoln, t. 1, Warszawa 2009, s. 285.
} 
[12]Paruch W., Między wyobrażeniami a dziataniami: wybrane aspekty przedmiotowe badań politologicznych nad myśla polityczną, „Polityka i Społeczeństwo" 2004/1.

[13][Paruch W., Myśl polityczna -refleksje metodologiczne o pojęciu,,Annales Universitatis Mariae Curie-Skłodowska. Sectio K Politologia” 1999/6.

[14] Paruch W., Trembicka K., Myśl polityczna we współczesnej polskiej politologii: modernizacja przedmiotu, strategii $i$ metody działań, [w:] Politologia $w$ Polsce.Stan badań i perspektywy, red. M. Ciochosz, K. Zamorska, Wrocław 2006.

[15] Skarzyński R., Historia myśli politycznej w ujęciu politologicznym. Zarys koncepcji, ,Studia Polityczne” 1992/1.

[16] Skinner Q., Znaczenie i rozumienie w historii idei,,,Refleksje” 2014/9.

[17] Szacki J., Dylematy historiografii idei oraz inne szkice i studia, Warszawa 1991.

[18] Waśkiewicz A., Interpretacja teorii politycznej,Warszawa 1998.

[19] Wokót dorobku warszawskiej szkoty historii idei, red. A. Kołakowski, Warszawa 2013.

“EVERYONE HAS ITS LINE IN THE SAND”. REFLEXIONS ON PARADIGMS (CONTEXTS AND PERSPECTIVES) IN POLITICAL THOUGHT RESEARCH

The main aim of the article is to compare the contexts in which the creator of the political thought (the object of research) and researcher himself, operate. The latter two may be either individuals or collective actors. In the analysis of power relations, political systems, internal or external affairs, the main challenge for the researcher(s) is to understand the influence that times, culture, language, social structure and competitive ideologies exert on a communicate (message and its form) being the research object.

In the process of analyzing and reconstructing political thought, the most obvious choice is a qualitative paradigm - critical theory or constructivism. The first paradigm is based on the premise that the reality is shaped by social, political, cultural, economic, gender, and ethnic values, which determine the cognitive process, its subjective and communicative character and the fact, that research results are intermediated by values. From the methodological point of view it means that the researcher has to take into account dialectic and dialogical character of the research. Constructivism is even more relative in its vision of social reality. The implication of the premise that reality is being constructed and reconstructed is the acceptance of the fact, that the researcher is also a creator of the results.

Thus the adapted methodology is based on assumptions of dialectic, hermeneutic and dialogical character of the research. Therefore, the output cannot be perceived as axiological neutral.

In order to describe past or contemporary ideas and the political thought inspired by them, one has to take up the strategy of the interpreter. In this case it would mean interpreting meaning within cultures that share common characteristics, but exemplify at the same time multitude of differences. A scholar specializing in political science should have competences that go beyond his/ her discipline. Should also be a historian, anthropologist, philosopher (ethic), specialist in linguistics, competent in psychology and in the cognitive processes.

Keywords: political thought, ideas, methodology, paradigms.

DOI:10.7862/rz.2015.hss.34

Przesłano do redakcji: październik 2014

Przyjęto do druku: październik 2015 